\title{
Sociale netwerken van ouderen
}

Over sociale netwerken van ouderen is de laatste jaren nogal wat te doen. Zo zouden ouderen in het kader van de participatiesamenleving voor steun en zorg eerst en vooral een beroep moeten doen op het eigen sociale netwerk, alvorens naar de overheid te kijken. In deze editie van Gerōn richten we ons op sociale netwerken van ouderen. Hoe groot zijn deze netwerken eigenlijk, hoe functioneren ze en is er diversiteit in sociale netwerken?

We nemen gemakkelijk aan dat sociale netwerken van ouderen kleiner worden met het verstrijken van de jaren, maar is dat ook zo? In hun bijdrage laten Bianca Suanet en Eric Schoenmakers zien dat de ontwikkeling van sociale netwerken toch wat genuanceerder ligt dan vaak aangenomen. $\mathrm{Zij}$ tonen dat de omvang van netwerken van ouderen over de jaren heen gemiddeld genomen niet krimpt, maar dat de samenstelling van de netwerken wel verandert.

Tina ten Bruggencate gaat in op een belangrijke functie van sociale netwerken, namelijk het vervullen van sociale behoeften. Wederkerigheid is hierin voor mensen van groot belang. Dat geldt overigens ook voor de relatie die het individu heeft met een groter geheel, zoals de samenleving.
De omvang en functie van sociale netwerken verschillen van mens tot mens. Cornel Vader is voorzitter van de stichtingsdirectie van het Leger des Heils. Zij hebben oog voor mensen aan 'de onderkant van de samenleving'. Voor deze mensen zijn sociale netwerken misschien nog wel meer van belang dan voor anderen, maar gelden er ook andere dynamieken. Sybren Kalkman beschrijft in zijn essay een niet alledaagse vorm van een sociaal netwerk op microniveau.

Als het over mensen gaat, gaat het al snel over hun relaties tot anderen. Er zijn weinig artikelen in dit nummer van Gerōn, of in andere nummers, die niet ergens een raakvlak hebben met dit thema. Of het nu gaat om duurzame inzetbaarheid (zoals het interview met Joyce Schaeffer), eenzaamheid (bijdrage Kamieke van de Riet) of manieren om over onze toekomst na te denken (bijdrage Froukje Sleeswijk Visser en Pieter Jan Stappers), telkens komt toch het belang van sociale netwerken aan de orde. Aristoteles (384 BC - 322 BC) zei het al: "De mens is een sociaal dier, hij is niet gemaakt om alleen te leven."

Inge Klück, Sybren Kalkman $\&$ Eric Schoenmakers 